International Journal of Instruction e-ISSN: 1308-1470 • www.e-iji.net
July $2018 \bullet$ Vol.11, No.3

p-ISSN: 1694-609X

pp. $277-290$

Received: $10 / 12 / 2017$

Revision: 19/03/2018

Accepted: 25/03/2018

\title{
Self-Assessment: The Effect on Students' Independence and Writing Competence
}

\author{
Ni Made Ratminingsih \\ Dr., Universitas Pendidikan Ganesha, Indonesia, made.ratminingsih@ undiksha.ac.id
}

A. A. I. N. Marhaeni

Prof., Universitas Pendidikan Ganesha, Indonesia, agung.marhaeni@ undiksha.ac.id

\section{P. D. Vigayanti}

M.A. Universitas Pendidikan Ganesha, Indonesia,diah.vigayanti@pasca.undiksha.ac.id

Self-assessment as one of authentic assessments has been currently implemented in EFL teaching pedagogy as to give more opportunity to the students to reflect on their own learning and progress. This study aims at investigating the effect of selfassessment on students' independence and writing competence. In the present study, two groups of junior secondary school students in Indonesia were investigated in their learning of English due to the use of self-assessment towards their independence and writing competence of three genre texts. The research used a post-test only control group design in which one group was given an experimental treatment using self-assessment, while the other received a conventional assessment utilizing teacher's assessment. There were two types of instruments used, questionnaire of students' independence and writing competence test which underwent validity and reliability testing beforehand. The data were analyzed using a one-way ANOVA and MANOVA. Before the inferential statistics analyses were conducted, the data were pre-requisitely tested in terms of normality, homogeneity, and multi co-linearity. The results prove that self-assessment has an effect on the students' independence and writing competence. Thus, teachers are recommended to promote the use of self-assessment to improve the students' independence and writing competence.

Keywords: authentic assessment, students' independence, self-assessment, teaching strategy, writing competence

\section{INTRODUCTION}

Teacher's task during or at the end of every lesson is to conduct assessment in order to know students' achievement towards the objective of the lesson. In common practices in Indonesian education context, teachers normally assess their students' work rather than 
involve them to assess their work. The students often get the score without understanding what mistakes they have done dealing with their work. On the contrary, the newest curriculum $(K-13)$ promotes the implementation of authentic assessment intensively, which requires the teachers to assign tasks which are meaningful in the sense that students are able to use the knowledge and skills they learn in their real life. Authentic assessment is defined as a form of assessment, in which the students are asked to perform real-world tasks that demonstrate the application of their knowledge and skills that they have learned (Mueller, 2006; Marhaeni \& Artini, 2015). The learning process moved beyond memorization of fact or theory, and it encourages the students to respond by using the knowledge they have learned (Mueller, 2006). One type of authentic assessment which can be used to assess language competence is selfassessment.

Self-assessment is a process of formative assessment during which the students reflect on and evaluate the quality of their work and their learning, judge the degree to which they reflect the explicitly stated goals or criteria, identify strengths and weaknesses in their work, and revise accordingly (Andrade \& Du, 2007). It plays a critical role in adjusting teaching for students' learning because assessment for learning provides feedback for both teacher and students to be engaged in teaching and learning process (Buyukkarci, 2014). There are two main activities in self-assessment: (1) monitor and evaluate the quality of their thinking and behaviour when learning and (2) identify strategies that improve their understanding and skills (McMillan \& Hearn, 2008). Hence, self-assessment occurs when students judge their own work to improve performance as they identify discrepancies between current and desired performance. The use of self-assessment as a strategy of self-reflection on the mistakes and weaknesses that the language students conduct in using the language (linguistic), organization of discourse, and style of language use (non-linguistic), which they should improve in the process of their learning (Marhaeni \& Artini, 2015). It is considered as innovation on the nature of testing which moves from catching what the students do not know into what they do. It helps them to demonstrate that they are making progress on their writing development, which can encourage their motivation and identify their own strengths and weaknesses (Nedzinskaite, Švenčionienè, \& Zavistanavičienè, 2006).

Writing is one of the four impotant language skills needs to be acquired by EFL students. This productive skill plays an important role as to enable them to create their own pieces of writing in different genre texts as required by the curriculum. It is a process of dicovering, assembling, delivering, reshaping, and revising ideas on paper (Meyers, 2003). It is seen as an essential element for the students' academic success considering that writing can reinforce grammatical structure, vocabulary, and even improve other language skills such as reading, listening, and speaking (Kellogg, 2008). On the other hands, competence is defined as a broader term which consists of three elements namely, skills, knowledge, and attribute. A skill is about doing something well and it is usually developed through training and practice. A knowledge is the information that people know which includes theories, facts, and procedures. An attribute is an inherent characteristic or quality and often expressed through what people think, do, and feel (University of Victoria, 2011). Hence, writing competence is a 
writing skill possessed by the students which reflects their knowledge and the way they think, do, and feel expressed in their writing.

Besides giving an effect on writing competence, self-assessment also affects towards students' independence. Independence means quality of working with less tutor support and less structured teaching materials (Broad, 2006). An independent student is someone who can manage his/her own learning to achieve their purpose and is not wholly dependant on teachers for it, is motivated to learn, and develop ability to reflect on their own learning (Robinson, 2004).

Researches on the use of authentic assessment have been conducted by several researchers, namely Javaherbakhsh (2010) had performed a research to investigate the effect of self-assessment on Iranian EFL learners' writing skill. The result showed that self-assessment has a significant effect on Iranian EFL learner's writing skills. In line with it, Birjandi and Siyyari (2011) investigated the effect of doing self- and peerassessments on paragraph writing performance as well as the self- and peer-rating accuracy of a sample of Iranian English major students. The result found that peerassessment was more effective in improving students' writing performance. However, both are not significantly different in improving the rating accuracy of the students. In addition, Panadero, et al. (2012) took a comparison of the effects of two different selfassessment tools: rubrics and scripts on self-regulation learning and self-efficacy. It proved that the use of scripts enhanced self-regulation more than rubrics did on the control group. Another study conducted by Meihami and Varmaghani (2013) on the use of self-assessment in EFL writing classroom. The result proved that the mean score of experimental group's writing proficiency was significantly different from the control group. A recent study conducted by Thongpai and Deerajviset (2017) discovered the significant effect of self-assessment on writing skill of Thai EFL students in different group of learning styles. The result indicated that the use of self-assessment were useful for most of students having different learning styles in revising their writing and pointing out their writing strengths and weaknesses. Meanwhile, concerning with the study on learning independence, Shroff, Trent, and Ng (2013) found out that e-portfolio could effectively improve students' learning independence. Similarly, Kurt (2014) investigated the use of collaborative assessment on college students' learning independence and the study proved that the entire process of the use of collaborative assessment involving students' views was fun and functional.

Considering the emprical findings from previous researches explained above, there has not been a research conducted on investigating the effect of self-assessment on two variables simultaneously, writing competence and learning independence. Thus, the aims of this study are to answer these questions.

1. Is there any significant effect of self-assessment on students' independence?

2. Is there any significant effect of self-assessment on students' writing competence?

3. Is there any significant simultaneous effect of self-assessment on students' independence and writing competence? 
Based on the above research questions, the hypotheses are formulated as follows.

1. There is a significant effect of self-assessment on students' learning independence.

2. There is a significant effect on the implementation of self-assessment on students' writing competence.

3. There is a simultaneous effect of self assessment on students' learning independence and writing competency.

\section{REVIEW OF LITERATURE}

\section{Self Assessment}

Self assessment is one type of authentic assessments which is implemented to indicate skills and competencies, representing problems and situations likely to be encountered in daily life (Collins, 2013). It is categorized as a formative assessment during which the students reflect on and evaluate the quality of their work and learning, judge the degree to which they reflect the explicitly stated goal or criteria, identify strengths and weaknesses in their work, and revise accordingly (Andrade \& Du, 2007). It is a strategy of self-reflection on the mistakes and weaknesses that the language leaners make in using the language (linguistic), organization of discourse, and style of language used (nonlinguistics), which they should improve in the process of their learning. There are three basic elements of self-assessment: assessment tasks, assessment criteria, and forms. First, assessment tasks deal with the learning activities which enable the students to demonstrate their achievement of the learning outcome. This means that they should not only do the writing activities, but more importantly also practice judging on their writing development. Second, assessment criteria cover dimensions that teachers use to judge how well a student has achieved the learning goals. Criteria can be set at the course level but are more commonly used at the assessment task level. Generally, criteria are made available to students at the beginning of the course or when the assessment is distributed. Third, the forms deal with the instruments of assessment (Marhaeni \& Artini, 2015). Checklist is a form of self-assessment from which the students reflect on what they have learned and how they have learned it (Fry, Ketteridge, \& Marshall, 2009).

There are three main steps of self-assessment process. First is self-monitoring in which the students pay deliberate attention on what they are doing in relation to external standards, such as language accuracy, text organization, and mechanics that they should follow in their writing. Next is self-judgment in which they judge on their achievement and progress toward the targeted performance. This step emphasizes on the establishment of standard and criteria which guide the students to make meaningful judgment of what they know and what they still need to know (Bruce, 2001). In this case, teachers can provide the rubric of assessing writing that can be used by the students to make judgment of their development. The last essential step is called learning targets and instructional correctives, in which the students select the subsequent learning objectives to improve on partially correct answers, misunderstandings, and even to make more extensive learning in order to enhance their performance. In this step, they can make decision in which part they have to work their writing out more intensively in order to improve their writing (McMillan \& Hearn, 2008). 
Self-assessment is not merely for assessment purpose, but it can also be used for teaching strategy. Self-assessment as a teaching strategy can be used as a process of metacognition. It comes from the idea that learning is not just a matter of transferring ideas from someone who is knowledgeable to someone who is not, but it is an active cognitive process that occurs when they interact with new ideas (Earl \& Katz, 2006; Pantiwati \& Husamah, 2017). Thus, the teacher should facilitate the students in their learning of the language to possess communicative competence both oral and written. In conducting self-assessment both teachers and students should realize their own role (O'Malley \& Pierce, 1996). The teachers' role is providing time to work that encourages decision making, drafting, reflecting, discussing, reading, and responding, as well as using information gathered from interactions with their students, while the students' role is learning how to choose writing topics and materials, engage in self-assessment, and set goals for learning. Collaboration between teacher and student is the key to successful use of self-assessment techniques in the classroom. Furthemore, when they are given the opportunities to self-assess, they take an active role in the entire writing process which covers writing, evaluating, revising, rewriting and evaluating by making use of the checklist provided (Marhaeni \& Artini, 2015).

\section{Students' Independence}

Besides the cognitive aspect, psychological factor like students' independence may affect on their success in language learning. There are different terms which often refer to the same thing, such as independent learning, autonomy, and self-accelerated learning (Broad, 2006). One similarity among those terms is its purpose to teach the students to learn for themselves and empower them to be responsible to reach the expected objectives. An independent learning is a self process of managing learning in order to construct knowledge and skills with a less dependence on teachers to direct it, it is more driven by intrinsic motivation, and followed by self-reflection along the learning process (Robinson, 2004). Thus, students' independence can be defined as the responsibility of the students to take actions of their own learning, such as to plan, to manage, and to reflect on what they should study in order to achieve the target. Studies prove that students' independence was influenced by the use of self assessment (Honsa, 2013; Panadero, Tapia \& Huertas, 2012).

\section{Writing Competence}

Competence refers to a terminology covering three elements: (1) skills which deal with the action of doing developed on the basis of training and practice, (2) knowledge, which concerns with information that people obtain including theories, facts, and procedures, and (3) attribute which covers an essential characteristic or quality and is often expressed through what people think, do, and feel (University of Victoria, 2011).

Competence in language learning is pioneered by Hymes to refer to the social and functional aspects to convey and interpret message and to negotiate meanings interpersonally within a specific context, where the focus is not only to develop the grammatical knowledge of language, but also to know when, where and to whom to use appropriate language in a communicative event (Richards \& Rodgers, 2001). In order to 
achieve this competence, there are two main types of communication that the teacher should teach, oral and written communication. Oral communication is taught through teaching listening and speaking, while written communication is taught through reading and writing. According to the Indonesian National Education Ministrial Regulation Number 22 Year 2006 about content standard of English for junior secondary school, the students are required to possess the standard competence to express meaning into written short functional text and long functional text of descriptive, narrative, recount, and procedure texts in order to interact with the environment. This signifies that the teaching of writing should be taught contextually by which the students are able to use their competence in their everyday life.

However, the reality shows that writing is a complex process. Most Indonesian students conveyed that it is the most difficult skill to be acquired (Ratminingsih, 2015). It is also proven the same as in other EFL contexts. A case study to Qatar students reported that writing is one of the most difficult and therefore a frustrating subject to teach in an ESL/EFL program (Al-Buainain, 2009). Pakistan secondary school students also experienced the same problems in writing (Javed, Juan, \& Nazli, 2013). To mention some of the problems in writing are: (1) they find it difficult to start on their writing, as it is not easy to express what they have in mind using a foreign language, (2) they often cannot develop their writing well due to their limitation in vocabulary, (3) they are unable to organize their writing coherently, and (4) they are concerned with the grammatical mistakes they make in their writing. (Ratminingsih, 2015:103).

Recent studies found that self-assessment is positively correlated with writing which is indicated by the improvements in students' writing which cover better qualities of ideas and content, organization, voice and mechanics (Andrade \& Du, 2007). Self-assessment is welcomed by the majority of their subjects and that it had a positive role in the whole ESL writing process (Wang \& Wang as cited in Tavakoli \& Ghoorchaei, 2009). They found that self-assessment is more helpful in self-editing and revising than in the composing process of writing. Self-assessment also had an effect on Iranian EFL students' writing skill (Javaherbakhsh, 2010; Birjandi \& Siyyari, 2011; Meihami \& Varmaghani, 2013). Furthermore, the implementation of self-assessment could improve the the writing of intermediate EFL students at a university in Thailand (Honsa, 2013). It was also proven that the students also had a positive perception towards its use (Ratminingsih et al., 2017). Thus, it can be summed up that self-assessment is an effective strategy to improve the writing performance of the students, since they have a good perception on it.

\section{METHOD}

\section{Research Design}

This experimental research used Post-Test Only Control Group Design. There were 425 seventh grade students as the population of the study which spread out into 13 classes in the academic year 2015/2016. Theoretically, the flow of the design is as follows.

Experimental Group

Control Group

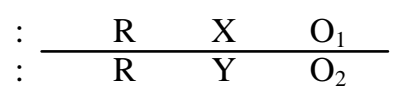

International Journal of Instruction, July $2018 \bullet$ Vol.11, No.3 
$\mathrm{R}$ : Random selection of the sample

$\mathrm{X}$ : Treatment given to the experimental group

$\mathrm{Y}$ : Treatment given to the control group

$\mathrm{O}_{1}$ : Experimental Group Posttest Result

$\mathrm{O}_{2}$ : Control Group Posttest Result

\section{Population and Sample}

The population of this study was 425 of seventh grade students of Government Junior High School in Indonesia, particularly in Klungkung Regency, Bali. The name of the school is SMPN 1 Semarapura. Random sampling technique was taken in order to determine two intact groups as the samples of the study consisted of 34 students in each class. One group was taught writing in which the students should learn to assess their own work by applying self-assessment, while the other group was taught writing using a conventional technque in which the teacher evaluated solely students' work.

\section{Instruments}

In collecting the data, the two main instruments used were questionnaire of students' independence and test of writing competence. The questionnaire covered 60 items and the tests of writing were short functional text that required the students to write an invitation and long functional texts in the form of descriptive text, that they should write a description of a favourite idol, and procedure text, in which they had to write the procedure of how to make food. Both the questionnaire and writing tests underwent content validity testing from two expert judges. Using the Gregory formula of analysis, the questionnaire was proven to have high content validity with $\mathrm{CV}=0.98$, while the writing competence tests were also proven to possess high content validity with $\mathrm{CV}=$ 1.00 . Then, they were tried out for empirical validity testing to find out the validity and reliability of the instruments. The results of try out showed that among 60 items of the questionnaire, there were 41 items calculated to be valid and further analysed their reliability using Cronbach's Alpha formula. From the calculation it was found that the questionnaire possessed very high reliability (0.91). Among those 41 valid items, there were 30 items which were selected for the questionnaire and distributed to the students in experimental and control groups. Meanwhile, the result of inter-rater reliability for the writing tests proved that they had very high reliability with reliability coefficient 0.97 for the short functional test (invitation), 0.81 for descriptive text, and 0.96 for procedure text.

\section{Procedure of Treatment}

Table 1 shows the different procedures of treatment between the experimental group and the control group in their learning process of writing a descriptive text. 
Table 1

The Table of Comparison between Self-assessment and Conventional Assessment.

\begin{tabular}{|c|c|}
\hline Conventional & Self-Assessment \\
\hline 1. Teacher-Structured & Teacher and students structured \\
\hline $\begin{array}{l}\text { The assessment tools, assessment task and } \\
\text { criteria are determined by the teacher. The } \\
\text { assessment process is also carried by the } \\
\text { teacher. }\end{array}$ & $\begin{array}{l}\text { The assessment tools, assessment task and criteria } \\
\text { are developed and determined by the teacher in } \\
\text { collaboration with the students. The students are } \\
\text { also involved in the process of evaluation. }\end{array}$ \\
\hline 2. Product-oriented & 2. Product as well as process-oriented \\
\hline $\begin{array}{l}\text { The evaluation are usually carried out at } \\
\text { the end of the learning process or } \\
\text { assessing the final product of the writing } \\
\text { itself by means of analytical scoring } \\
\text { rubric. }\end{array}$ & $\begin{array}{l}\text { The writing score are usually carried out at the } \\
\text { end of each writing steps by means of self- } \\
\text { assessment checklist and analytical scoring } \\
\text { rubric. }\end{array}$ \\
\hline $\begin{array}{l}\text { 3. Writing Process: Drafting-Final } \\
\text { Writing }\end{array}$ & $\begin{array}{l}\text { 3. Writing Process: Pre-writing, writing, revising, } \\
\text { Proof-reading. }\end{array}$ \\
\hline $\begin{array}{l}\text { The writing process is mainly done by } \\
\text { creating a draft and revising the draft } \\
\text { based on feedback given by the teacher. }\end{array}$ & $\begin{array}{l}\text { The writing process involves more complex } \\
\text { processes that emphasize the students' } \\
\text { involvement on each of the process. }\end{array}$ \\
\hline 4. Individual & 5. Collaboration with peers \\
\hline $\begin{array}{l}\text { The students write their draft and revise it } \\
\text { based on the suggestion given. The } \\
\text { students only focuses on the quality of } \\
\text { their writing product (individual focus) }\end{array}$ & $\begin{array}{l}\text { Proofreading phase enables the students to read, } \\
\text { judge and learn the quality of their peer work and } \\
\text { at the same time they get input from their peers of } \\
\text { how to improve the quality of their writing. }\end{array}$ \\
\hline
\end{tabular}

\section{Data Analysis}

The collected data were then analysed descriptively focusing on the analysis of the central tendency (mean, median, mode, range, standard deviation, and variance) and inferentially using one-way ANOVA to analyse the first and the second hypotheses, that is the effect of self-assessment on students' independence and its effect on writing competence, while to analyse the simultaneous effect of self-assessment and writing competence, one-way MANOVA was used. Before the hypothesis testing in the form of inferential statistics was conducted, the data were also pre-requisitely tested in terms of normality and homogeneity of variance and covariance, and multi co-linearity. Normality testing was administered through Kolmogorov-Smirnov formula, homogeneity testing was carried out through Levene's test of equality of error variance, Box's $M$ was used to analyse the covariance, and multi co-linearity testing was measured by using Pearson Product Moment formula calculated by SPSS 16.0. Below are the results of those tests.

\section{FINDINGS}

After completing all of the requirements in terms of normality, homogeneity, variance and covariance, and multi co-linearity. The results of descriptive and inferential statistics analyses are presented in table 1 and 2 . 
Table 2

The Summary of the Calculation of Central Tendency and Dispersion

\begin{tabular}{lllll}
\hline \multirow{2}{*}{ Statistics } & \multicolumn{3}{c}{$\begin{array}{c}\text { A1 } \\
\text { (Experimental Group) }\end{array}$} & \multicolumn{1}{c}{$\begin{array}{c}\text { A2 } \\
\text { (Control Group) }\end{array}$} \\
\cline { 2 - 5 } Sum & Y1 & Y2 & Y1 & Y2 \\
Mean & 3670 & 2817 & 3518 & 2696 \\
Median & 107.94 & 82.85 & 103.47 & 79.29 \\
Modes & 108 & 82.5 & 103.5 & 78.5 \\
Max & 108 & 82 & 103 & 77 \\
Min & 127 & 91 & 120 & 89 \\
Range & 91 & 75 & 86 & 73 \\
Variance & 36.00 & 16 & 34.00 & 16 \\
SD & 87.51 & 13.04 & 64.01 & 15.06 \\
\hline
\end{tabular}

Table 1 shows that (1) the mean score of the students' independence treated by using self-assessment is 107.94. It is higher than the mean score of those treated by conventional assessment, 103.4 and (2) the mean score of the students' writing competence taught by using self-assessment is 82.85 , it is also higher than the mean score of those treated by conventional assessment, that is 79.29. Whether or not these differences of mean scores are significant, tables below show the results of ANOVA and MANOVA analyses.

Table 3

Finding on the Effect of Self-assessment on Students' Independence

\begin{tabular}{llllll}
\hline \multicolumn{1}{c}{ Source } & Type III Sum of Squares & Df & Mean Square & F & Sig. \\
\hline Corrected Model & $339.765^{\text {a }}$ & 1 & 339.765 & 4.485 & .038 \\
& 759813.882 & 1 & 759813.882 & $1.003 \mathrm{E} 4$ & .000 \\
A & 339.765 & 1 & 339.765 & 4.485 & .038 \\
Error & 5000.353 & 66 & 75.763 & & \\
Total & 765154.000 & 68 & & & \\
Corrected Total & 5340.118 & 67 & & & \\
\hline
\end{tabular}

a. R Squared $=.064$ (Adjusted R Squared $=.049)$

The result of the calculation using one-way ANOVA shows that the difference between students' independence treated by using self-assessment and conventional assessment shows the value of $F=4.485$ and the value of significance 0.038 . Considering the criteria for rejection (sig. $<0.05$ ), this means that the null hypothesis (Ho) is rejected. Thus, the first hypothesis confirms that there is a significant effect of self-assessment on the seventh-grade students' independence. 
Table 4

Finding on the Effect of Self-assessment on Writing Competence

\begin{tabular}{llllll}
\hline \multicolumn{1}{c}{ Source } & Type III Sum of Squares & Df & Mean Square & F & Sig. \\
\hline Corrected Model & $211.765^{\text {a }}$ & 1 & 211.765 & 14.748 & .000 \\
& 447120.529 & 1 & 447120.529 & $3.114 \mathrm{E} 4$ & .000 \\
A & 211.765 & 1 & 211.765 & 14.748 & .000 \\
Error & 947.706 & 66 & 14.359 & & \\
Total & 448280.000 & 68 & & & \\
Corrected Total & 1159.471 & 67 & & & \\
\hline
\end{tabular}

a. R Squared $=.183$ (Adjusted R Squared $=.170$ )

The result of the calculation of One-Way ANOVA shows that the difference between students' writing competence treated using self-assessment and conventional assessment has the value of $F=14.748$ and the value of significance 0.000 . Thus, there is a significant effect of self-assessment on the students' writing competence.

Table 5

Finding on the Effect of Self-assessment on Students' Independence and Writing Competence

\begin{tabular}{lllllll}
\hline Effect & & Value & F & Hypothesis df & Error df & Sig. \\
\hline & Pillai's Trace & .998 & $1.666 \mathrm{E} 4^{\mathrm{a}}$ & 2.000 & 65.000 & .000 \\
& Wilks' Lambda & .002 & $1.6664^{\mathrm{a}}$ & 2.000 & 65.000 & .000 \\
& Hotelling's Trace & 512.521 & $1.666 \mathrm{E} 4^{\mathrm{a}}$ & 2.000 & 65.000 & .000 \\
& Roy's Largest Root & 512.521 & $1.666 \mathrm{E} 4^{\mathrm{a}}$ & 2.000 & 65.000 & .000 \\
\hline $\mathrm{A}$ & Pillai's Trace & .194 & $7.819^{\mathrm{a}}$ & 2.000 & 65.000 & .001 \\
& Wilks' Lambda & .806 & $7.819^{\mathrm{a}}$ & 2.000 & 65.000 & .001 \\
& Hotelling's Trace & .241 & $7.819^{\mathrm{a}}$ & 2.000 & 65.000 & .001 \\
& Roy's Largest Root & .241 & $7.819^{\mathrm{a}}$ & 2.000 & 65.000 & .001 \\
\hline
\end{tabular}
a. Exact statistic

b. Design: + A

Table 4 shows that MANOVA analysis proves the significant values of $\mathrm{F}$ for Pillai's Trace, Wilks Lambda, Hottelings' Trace, and Roy's Largest Root are lower than 0.05. Thus, there is a significant simultaneous effect of self-assessment on the seventh-grade students' learning independence and writing competence.

\section{DISCUSSION AND CONCLUSION}

Based on the data analysis, it can be discussed that the students show their responsibility to accomplish the task given using self-assessment. During treatments, the students in experimental group were ready to accomplish their writing assignment through the use of checklist and analytical scoring rubric that support them to write a better writing. Being guided by the use of checklist and analytical scoring rubric, they could evaluate their writing in terms of expressing their ideas and its organization (Sharma, et al, 2016; Millan \& Hearn, 2008; Ross, 2006; Nedzinskaite, Švenčionienè, \& Zavistanavičienė, 2006; Robinson, 2004). 
The self-assessment also made them aware of their mistakes of grammatical usage assisted with the checklist and rubric. The growing sense of responsibility was also demonstrated by the students' working habit. By having the students to self-evaluate, they learned to judge their work based on the task requirements. Self-assessment allowed them to understand the standard of performance expected from them, to monitor their own performance and to know what they can do to improve it (McMillan \& Hearn, 2008; Andrade \& Du, 2007). This habit helped them develop the quality of their work and understand how to achieve it with less guidance given by the teacher. Since they were given a set of criteria, they found it easier to accomplish their task and finish their work on time. This result is in line with Wang and Wang's finding (in Tavakoli \& Ghoorchaei, 2009; Ratminingsih et al., 2017), that the students had a positive response toward the use of self-assessment throughout the whole process of writing, and it was significantly helpful in self-editing and revising which caused the students' writing better. Additionally, the students in the experimental group were showing more active participation by their involvement in the process of learning to write and practicing evaluation on their work. Therefore, they became more independent and responsible for their own learning. They were more conscious to take ownership toward their learning (Pantiwati \& Husamah, 2017; Honsa, 2013; Panadero, et al., 2012; Broad, 2006; Robinson, 2004; Holec in Gardner, 2000).

In accordance with the effect of self-assessment on writing competence, it is obvious that the external standards in self-assessment provided clear criteria of a good writing. The students were given a set of fixed criteria of how their work was judged in the form of checklist and rubric. Self-assessment helped the students to internalize the standards by which their product and performances were judged (McMillan \& Hearn, 2008; Andrade \& Du, 2007;Wiggins, 1990). They knew how to write well by comparing their work against the criteria, reflect and do revision. They had clear guidelines what to do and how to improve their writing after reflecting on their work (McMillan \& Hearn, 2008; Andrade \& Du, 2007). Hence, the result of this current study supports the previous researches by Javaherbakhsh (2010), Birjandi \& Siyyari (2011), and Meimahami \& Varmaghani (2013), which prove the effect of self-assessment towards students' writing performance. A good writing was produced when they were given opportunity to self-assess their writing product that needed to be revised along the process. It provided the opportunity for feedback. The students who were treated by self-assessment got frequent feedback from self-realization after anlyzing their own writing using checklist and analytical scoring rubric, which was strenghthened with teacher's feedback and peer's feedback during the process of writing, so that the students were able to recognize their strengths and weaknesses from several directions. It also helped them to identify what aspects they were good at and what aspects of their writing needed to be improved. This led them to be more participative, active and motivated to learn, thus they were able to complete the writing task (Nedzinskaite, et al. (2006). In fact, the teachers' feedback plays an important role for their competence (Fry, et al., 2009; Nicol, 2007; Yorke, 2003). As well, the students' work also gave feedback to the teachers to revise on their teaching strategy. Henceforth, both teacher and students could reflect on the learning and teaching process by utilising self assessment 
(Buyukkarci, 2014; Meihami \& Varmaghani, 2013). On the contrary, students in the control group they merely submitted the product of their work to be evaluated by the teacher and the students did the revision based on the teacher's comment without the support of checklist and analytical scoring rubric which guided them in the process of revision as well there was no proof-reading assistance from peers. Therefore, the students revised their writing limitedly based on their own understanding.

It can be concluded that self-assessment is powerful and beneficial to give an effect toward the students' independence and writing competence. The students treated with self-assessment performed better on students' learning independence than those treated with conventional assessment, and there is an effect of self-assessment on the students' writing competence. The students taught with self-assessment performed better on students' writing competence than those treated with conventional assessment. Therefore, it is suggested that teachers can maximize the use of self-assessment as an alternative teaching and learning strategy to be implemented in writing classes. For the students, it is suggested to continuously practice using self-assessment to develop their metacognitive skills in reflecting on their learning, being responsible of their learning, and being motivated to learn, so that they can improve their writing competence.

\section{REFERENCES}

Al-Buainain, H. (2009). Students' writing errors in ESL: A case study. A Research Report. Qatar: Department of Foreign Language, Qatar University.

Andrade, H. \& Du, Y. (2007). Students responses to criteria-referenced self-assessment. Assessment and Evaluation in Higher Education, 32(2), 159-181.

Birjandi, P. \& Siyyari, M. (2011). Self-assessment and peer-assessment: A comparative study of their effect on writing performance and rating accuracy. Iranian Journal of Applied Linguistics, 13(1). 23-45.

Broad, J. (2006). Interpretations of independent learning in further education. Journal of Further and Higher Education, 30(2), 119-143.

Bruce, L. B. (2001). Student self-assessment: Making standards come alive. Classroom Leadership, 5(1), 1-6.

Buyukkarci, K. (2014). Assessment beliefs and practices of language teachers in primary education. International Journal of Instruction, 7(1), 108-119.

Collins, R. (2013). Authentic Assessment: Assessment for Learning. Curriculum and Leadership Journal, 11(7).

Earl, L. \& Katz, S. 2006. Rethinking classroom assessment with purpose in mind. Manitoba: Manitoba Education, Citizenship and Youth.

Fry, H., Ketteridge, S. \& Marshall, S. (2009) A handbook for teaching and learning in higher education. Third edition. Oxon: Routledge. 
Gardner, D. (2000). Self-assessment for autonomous language students. Links \& Letters $7(1), 49-60$.

Honsa, S. (2013). Self-assessment in EFL writing: A study of intermediate EFL students at a Thai University. Voices in Asia Journal, 1(1), 34-57.

Javaherbakhsh, M. R. (2010). The impact of self-assessment on Iranian EFL students' writing skill. English Language Teaching, 3(2), 213-218.

Javed, M., Juan, W.X., \& Nazli, S. (2013). A study of students' assessment in writing skills of the English language. International Journal of Instruction, 6(2), 129-144.

Kellogg, R. T. (2008). Training writing skills: A cognitive developmental perspective. Journal of Writing Research, 1(1), 1-26.

Kurt, M. (2014). Collaborative assessment: Fostering ownership in assessment. Education, 134(3), 332-339.

Marhaeni, A.A.I.N. \& Artini, L.P. (2015). Asesmen autentik dan pendidikan bermakna: Implementasi Kurikulum 2013. Jurnal Pendidikan Indonesia, 4(1), 499-511.

McMillan, J.H. \& Hearn, J. (2008). Student self-assessment: The key to stronger student motivation and higher achievement. Educational Horizons, 87(1), 40-49.

Meihami, H. \& Varmaghani. Z (2013). The implementation of self-assessment in EFL writing classroom: An experimental study. International Letters of Social and Humanistic Sciences, 9(1), 39-48.

Meyers, A. (2003). Composing with confidence: Writing effective paragraphs essays. New York: Addison Wesley Longman Inc.

Mueller, J. (2006). The authentic assessment toolbox. Retrieved January 3rd, 2016 from http://jonathan.mueller.faculty.noctrl.edu/toolbox/standardtypes.htm

Indonesian National Education Ministerial regulation number 22 year 2006 about content standard.

Nedzinskaite, I., Švenčionienè, D., \& Zavistanavičienè, D., (2006). Achievements in language learning through students' self-assessment. Studies about Languages. 8(1), 84-87.

Nicol, D. (2007). Laying a foundation for lifelong learning: Case studies of e-assessment in large 1st-year classes.' British Journal of Educational Technology, 38(4), 668-678.

O’Malley, J. M., \& Pierce, L. V. (1996). Authentic assessment for English language students: Practical approaches for teachers. New York: Addison-Wesley Publishing Company.

Panadero, E., Tapia, J. A., \& Huertas, J. A. (2012). Rubrics and self- assessment scripts effects on self-regulation, learning and self-efficacy in secondary education. Learning and Individual Differences, 22(1), 806-813. 
Pantiwati, Y. \& Husamah. (2017). Self and peer assessments in active learning model to increase metacognitive awareness and cognitive abilities. International Journal of Instruction, 10(4), 185-202.

Paris, S. G. \& Paris, A. H. (2001). Classroom applications of research on self-regulated learning. Educational Psychologist, 36(2), 89-101.

Ratminingsih, N.M., Artini, L.P., \& Padmadewi, N.N. (2017). Incorporating self and peer assessment in reflective teaching practices. International Journal of Instruction, 10(4), 165-184.

Ratminingsih, N.M. (2015). The use of personal photographs in writing in project-based language learning: A case study. The New English Teacher 9(1), 102-118.

Richards, J.C. \& Rodgers, T.S. (2001) Approaches and methods in language teaching. Second edition. Cambridge: Cambridge University Press.

Robinson, B. (2004). What is an independent learner? Retrieved January 3, 2016 from http://www. open.edu.cn/elt/8/17.htm

Ross, J. A. (2006). The reliability, validity, and utility of self-assessment. Practical Assessment Research \& Evaluation, 11(10), 1-13.

Sharma, R., Jain, A. Gupta, N., Garg, S., Batta, M., \& Dhir, S. K. (2016). Impact of self -assessment by students on their learning. International Journal of Applied and Basic Medical Research, 6(3), 226-229.

Shroff, R. H., Trent, J., \& Ng, E. M. (2013). Using e-portfolios in a field experience placement: Examining student-teachers' attitudes towards learning in relationship to personal value, control and responsibility. Australasian Journal of Educational Technology, 29(2). 143-160.

Tavakoli, M. \& Ghoorchaei, B. (2009). On the relationship between risk-taking and self-assessment of speaking ability: A case of freshman EFL students. The Journal of Asia TEFL 6(1), 1-27.

Thongpai, J., \& Deerajviset, P. (2017). Effects of self-assessment on writing of Thai EFL students in different groups of learning styles. In ASEAN/Asian Academic Society International Conference Proceeding Series.

University of Victoria. (2011). What makes up a competency. Retrieved March 15th, 2016 from www.uvic.ca/.../corecompetencies/What_makes_up_a_competency_info.

Wiggins, G. (1990). The case of authentic assessment. Practical assessment, research \& evaluation, 2(2), 1-3.

Yorke, M. (2003). Formative assessment in higher education: Moves towards theory and the enhancement of pedagogic practice. Higher Education, 45(4), 477-501. 